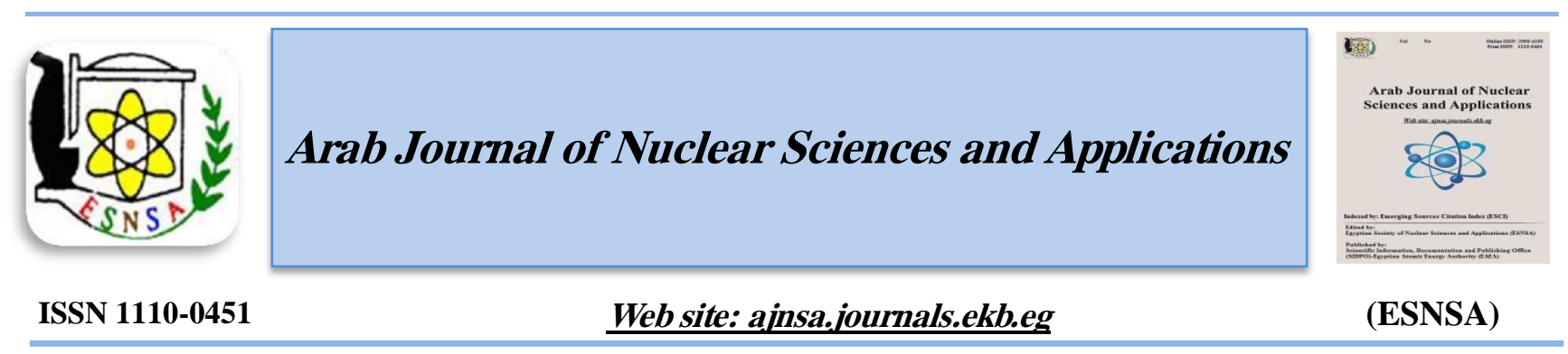

\title{
On the Possibility of Urea Peroxide Formation in $\gamma$ - Irradiated Urea Aqueous Solution - A Spectroscopic Study
}

\author{
Kh. A. Sife-Eldeen \\ National Center for Radiation Research and Technology (NCRRT), Atomic Energy Authority
}

Received $15^{\text {th }}$ Dec. 2017 Accepted $12^{\text {th }}$ Nov. 2018
In order to investigate the possibility of urea peroxide formation in $r$-irradiated urea aqueous solutions (UAS), energy-dispersive x-ray (EDS), mass (MS), 1H-NMR, and Raman spectral studies were conducted on UAS and its solid residues (SR) that remain after water evaporation. Spectroscopic data of SR for both irradiated and unirradiated samples were analyzed and compared. EDS data showed an increase in the oxygen content in SR of UAS upon radiolysis. Comparison of mass spectrum of RS of irradiated sample and that of urea shows a significant increase in $\mathrm{m} / \mathrm{z} 16$ peak intensity of $\mathrm{O}^{+}$as well as $\mathrm{m} / \mathrm{z} 61$ of M+1in the former. The 1H-NMR spectrum of SR of an irradiated sample shows a signal down field shift of urea protons, as well as the appearance of new signals, which were assigned to $\mathrm{H}_{2} \mathrm{O}_{2}$. The Raman spectral study of both RS and UAS evinces differences in all band positions and intensities for irradiated samples relative to their corresponding unirradiated samples. As a consequence of this study, it seems that the possibility of urea peroxide formation in $\gamma$-irradiated UAS cannot be ruled out.

Keywords: Urea peroxide/ Urea/ $\gamma$-Radiation/Raman/1H-NMR/Mass spectrometry/ Energy-dispersive x-ray spectrometry

\section{Introduction}

Owing to the presence of two lone electron pairs in the $\mathrm{H}_{2} \mathrm{O}_{2}$ molecule and its specific geometry, it can form peroxohydrates with a variety of hydrophilic compounds [1]. Therefore, in aqueous solutions, hydrogen peroxide binds by hydrogen bonding to several proton acceptor such as urea [2], acetone [3] and Polyvinylpyrrolidone (PVP)[4] forming hydrogen peroxide adducts. Urea forms spontaneously an adduct (1:1) with hydrogen peroxide, $\mathrm{CO}\left(\mathrm{NH}_{2}\right)_{2} \bullet \mathrm{H}_{2} \mathrm{O}_{2}$, i.e. urea peroxide (UHP), which provides a good means for stabilizing $\mathrm{H}_{2} \mathrm{O}_{2}[2]$. This occurs in aqueous solutions due to the higher basicity of urea compared to that of water. The $\mathrm{pKa}$ of the first is 26.9[5] and that of the second is 15.7[6]. M. Das, et al., studied both the IR and UV spectra of UHP [7]. They reported that the IR and UV spectra of urea and UHP are similar to a great extent. This similarity was attributed to the weak interaction between urea and hydrogen peroxide. UHP, as an oxidizing agent, has been found to be extremely useful in several applications such as bleaching [8], sterilization [9], and the removal of metal impurities from silicon-containing substrates (e.g. solar cell substrates) [10]. Moreover, UHP is added to fermentation media in an amount sufficient to substantially reduce the level of bacterial contaminants in biofuel production [11]. Moreover, a preliminary study [12] reveals that second - order nonlinear optical activity (NLO) of UHP is better than that of urea. Accordingly, it has been reported that, NLO has a promising application in the field of opto - electronics such as laser sources.

Hydrogen peroxide is considered to be one of the most important water radiolysis products [13]. On the other hand, urea is relatively stable to ionizing

Corresponding author: sifekhdr@hotmail.com

DOI: 10.21608/ajnsa.2018.2236.1022.

(C) Scientific Information, Documentation and Publishing Office (SIDPO)-EAEA 
radiation in aqueous solutions [14]. As a matter of fact, the presence of hydrogen peroxide in aqueous solutions increases their electrical conductivity [15]. Moreover, the author of the present investigation has previously reported that $\gamma$ radiolysis significantly increases the electrical conductivity of (6M) aqueous urea solution [16]. Taking the previous data into consideration, it was viewed as important to ask a question, could UHP be formed upon $\gamma$-radiolysis of urea aqueous solutions (UAS)? Therefore, spectroscopic methods, such as EDS, Raman, 1H-NMR and MS, were used for tracing UHP in this solution.

\section{Experimental}

Sample preparation and radiolysis

All chemicals employed in this study are of the analytical grade and were used as received. All of the urea solutions $(6 \mathrm{M})$ used in this study were prepared using double-distilled water. Irradiation was performed using a ${ }^{60} \mathrm{Co}$ source (India Gamma chamber $4000 \mathrm{~A}$,) at a dose rate of $2.86 \mathrm{kGy} / \mathrm{h}$, for a total dose of $192.4 \mathrm{kGy}$. Radiolysis was carried out $\left(\right.$ at $\approx 40^{\circ} \mathrm{C}$ ) in $50 \mathrm{ml}$ glass bottles with tight glass stoppers which were cleaned using standard methods [17]. Fricke solution was used as a reference dosimeter to determine absorbed dose rates of the radiation facility, according to ASTM E1026-04e1 Standard Practice. The absorbed radiation dose correction was applied for the difference in the electron densities of urea and Fricke solutions. The solid residues (SR) were obtained by the storage of UAS in a refrigerator (5 ${ }^{\circ} \mathrm{C} \pm 1$ ) till dryness. The obtained SR is nominated as ppt-1 and ppt-2, for solid residue obtained from unirradiated and irradiated (6M) UAS respectively.

\section{Spectroscopic measurements}

Energy-dispersive $x$-ray spectrometry (EDS)

The elemental analyses for $\mathrm{C}, \mathrm{N}$, and $\mathrm{O}$ was carried out using. energy-dispersive $\mathrm{x}$-ray spectrometry (EDS). The analyses were taken by Joel (JED-2300) equipment. The acquisition parameters are listed below:

Acc. Voltage: $30 \mathrm{kV}$

Probe current: $1 \mathrm{nA}$

\section{Mass spectrometry}

Mass spectra were obtained at an ionization potential of $70 \mathrm{eV}$ (EI mode), scanned on a
Finnigan mat SSQ 7000 (Thermo instrument systems inc., USA). The direct insertion probe (DIP) was used for the analysis of SR. The temperature programme applied was as follows: $30^{\circ} \mathrm{C}\left(0.5 \mathrm{~min}\right.$.) to $200^{\circ} \mathrm{C}\left(1.0 \mathrm{~min}\right.$.) at $100^{\circ} \mathrm{C} / \mathrm{min}$.

\section{NMR spectroscopy}

1H-NMR spectra were recorded on a Varian Oxford $300 \mathrm{MHz}$ spectrometer in DMSO-d6 at 25 ${ }^{\circ} \mathrm{C}$ and referenced internally to the residual proton impurity in DMSO. D2O shake test has been performed with D2O - Merck ( $>99$ atom \% D) at room temperature.

\section{Raman spectroscopy}

Dispersive Raman microspectrometer (Bruker Senterra) equipped with a $532 \mathrm{~nm}$ source with excitation power of $20 \mathrm{~mW}$ was used, with 50 $\times 1000 \mathrm{~m} \mu$ aperture setting, to obtain Raman spectra at room temperature. Each spectrum was recorded in the range $50-4500 \mathrm{~cm}^{-1}\left(9-18 \mathrm{~cm}^{-1}\right.$ resolution).

\section{Results and Discussion}

It is well known that one of the main water radiolysis products is hydrogen peroxide [13]. Taking into account that hydrogen peroxide binds to urea in the aqueous phase forming UHP [2], the presence of a $\mathrm{C}=\mathrm{O}$ dipoles and, to a lesser extent a $\mathrm{N}-\mathrm{C}$ dipoles, allows the amide to act as $\mathrm{H}$-bond acceptor. On the other hand, the presence of $\mathrm{N}-\mathrm{H}$ dipoles allows amides to function as $\mathrm{H}$-bond donors as well. Thus, urea can participate in hydrogen bonding with an oxygen atom which can accept a proton. Whereas, the nitrogen atoms can donate and accept proton of $\mathrm{N}-\mathrm{H}$ bonds [18] (Figure1). Consequently, a model can be proposed in which the $\mathrm{C}=\mathrm{O}$ group of urea and one of the two $\mathrm{NH}_{2}$ groups are hydrogen bonded to hydrogen peroxide. At the same time the second $\mathrm{NH}_{2}$ group is kept free. This model is similar to a model proposed by Ray et al, for the hydrogen bonding of urea to siloxane [19]. Urea is known to be stable towards ionizing radiation in aqueous solutions [14]. The previously mentioned facts led us to believe that UHP may be formed upon $\gamma$ radiolysis of UAS. Since, $\gamma$-irradiation of UAS at ambient temperature $\left(\approx 40^{\circ} \mathrm{C}\right)$ fulfils the presence of hydrogen peroxide and urea in circumstances 


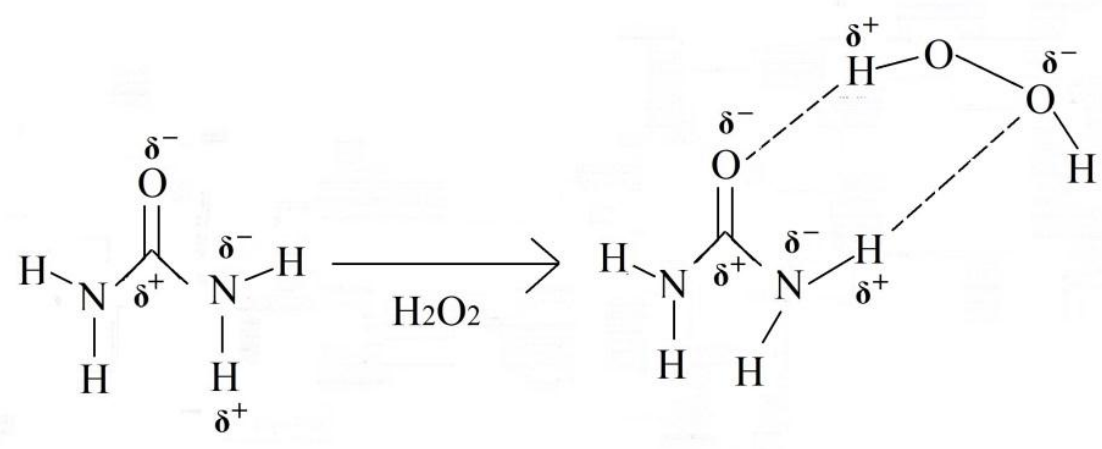

Urea

Urea Peroxide

Figure (1) A proposed model for hydrogen bonding of urea with hydrogen peroxide

quite similar to that suitable for the formation of UHP [2]. On the other hand, in a previous work, it was found tha $\gamma$-radiation-induced electrical conductivity of UAS is significant at $6 \mathrm{M}$ [16]. Taking in consideration that hydrogen peroxide almost increases the electrical conductivity of its aqueous solutions [15]. Therefore, it can be proposed that there is a relationship between the radiation-induced electrical conductivity in the UAS and UHP formation. Consequently, the 6M UAS was selected for this study, since at this concentration the maximum radiation induced electrical conductivity is obtained [16]. At this concentration it was found that the radiation induced electrical conductivity increases up to 250 kGy [16]. Therefore, in order to obtain a considerable yield of UHP, the UAS was irradiated with $194 \mathrm{kGy}$ absorbed dose. In the present work the prospective formation of UHP via the $\gamma$ radiolysis of $(6 \mathrm{M})$ UAS was investigated by EDS, Mass, H-NMR, and Raman, spectroscopic methods.

\section{EDS}

The elemental analyses of $\mathrm{C}, \mathrm{N}$, and $\mathrm{O}$ was carried out, on ppt-1 and ppt-2 using EDS. The results presented in (Table 1). include $\mathrm{C} \%, \mathrm{~N} \%$, and $\mathrm{O} \%$ (element $\%$ was calculated relative to total $\mathrm{C} \%$, $\mathrm{N} \%$, and $\mathrm{O} \%$ values) for both ppt-1 and ppt-2. Here we focus our discussion on $\mathrm{O} \%$ of ppt-1 and ppt-2, which was used as an indicator for the total oxygen content in the precipitate. It is clearly shown in Table (1), that $\mathrm{O} \%$ is higher in ppt-2 than ppt-1. This observation suggests the formation of an oxygen-rich compound in ppt- 2 .

Table (1) Elemental composition of EDS analyzed ppt-2

\begin{tabular}{|c|c|c|c|}
\multicolumn{5}{|c|}{ and ppt-1 samples } \\
\hline Sample & $\mathrm{C} \%$ & $\mathrm{~N} \%$ & $\mathrm{O} \%$ \\
\hline ppt-1 & 18.16 & 40.61 & 41.23 \\
\hline ppt-2 & 16.19 & 35.75 & 47.34 \\
\hline
\end{tabular}

As a matter of fact, it is concluded that the UAS has the ability to form urea hydrate crystal on the positive side of $0{ }^{\circ} \mathrm{C}$ up to $+15.2{ }^{\circ} \mathrm{C}$ [20]. This conclusion explains the higher $\mathrm{O} \%$ of ppt-1 relative to urea, which is probably due to the formation of urea hydrate.

\section{Mass spectrometry}

The comparison of a measured mass spectrum to a reference one is an effective intuitive identification method. In our case, peak intensities of the mass spectrum of ppt-2 (Figure 2A) differ completely from that of urea [21] (Figure 2B). These differences will be discussed in the following sections. 

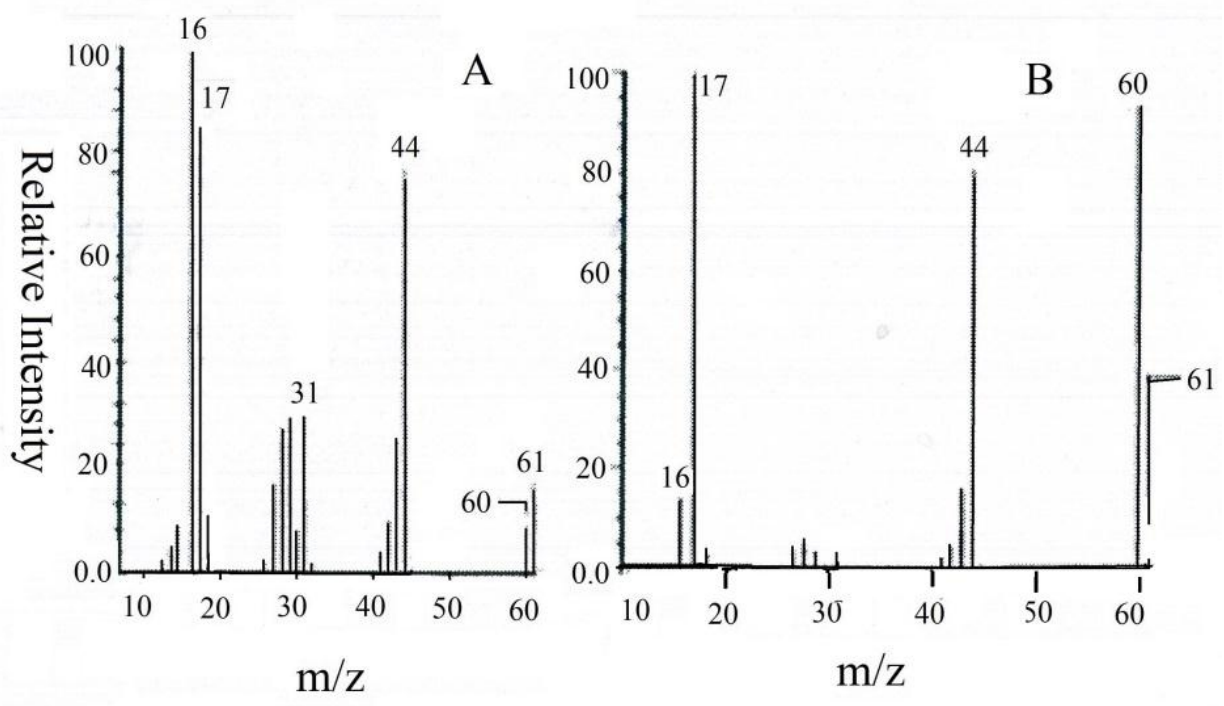

Figure (2) Mass spectra of (A) ppt-2, and (B) of urea

Peak of $\mathrm{O}^{+}(\mathrm{m} / \mathrm{z}=16)$

It can be seen from (Figure 2A) that the base peak in the mass spectrum of ppt- 2 is at $m / z=16$. It is believed that $\mathrm{m} / \mathrm{z}=16$ is assigned to $\mathrm{O}^{+}$[23], which can be released from peroxides [22]. When the spectrum of ppt-2 (Figure 2A) and that of urea (Figure 2B) are compared, it is evident that the relative intensity of the peak at $\mathrm{m} / \mathrm{z}=16$ is more abundant in the former. In fact urea peroxide tends to decompose to urea, water, and a single oxygen atom [22] (Scheme 1). Therefore, the formed single oxygen atom can be ionized to oxygen ion $(\mathrm{m} / \mathrm{z} 16)$ in the ion source.

\section{Enhancement of $M+1(\mathrm{~m} / \mathrm{z}=61)$ peak}

M $(\mathrm{m} / \mathrm{z}=60)$ and $\mathrm{M}+1(\mathrm{~m} / \mathrm{z}=61)$ peaks were compared in the spectra of ppt-2 (Fig. 2A) and urea (Fig. 2B). It can be seen that, contrary to the mass spectrum of urea, ppt-2 spectrum shows $M+1$ peak much stronger than $\mathrm{M}$ peak. This could be due to the formation of [urea $+\mathrm{H}]^{+}$. Consequently, a proton or hydrogen atom donor should be present with urea. It should be mentioned that $\mathrm{H}_{2} \mathrm{O}_{2}$ is functioning as a hydrogen atom donor [23]. Moreover, it was reported that molecular ion $\left(\mathrm{M}^{+}\right)$abstraction of a hydrogen atom gives rise to ions at $\mathrm{M}+1$ in the case of some compounds such as that contain amino group [24].

\section{Detection of $\mathrm{m} / \mathrm{z}, 34$ and 33}

Ions at $\mathrm{m} / \mathrm{z}=34$ were detected, which can be related to $\mathrm{H}_{2} \mathrm{O}_{2}$ [25]. Moreover, it should be mentioned that another ion was detected at $\mathrm{m} / \mathrm{z}=$ 33, which was attributed to $\mathrm{HO}_{2}{ }^{+}$ion [25]. It was concluded that hydrogen peroxide could be detected via ions at $\mathrm{m} / \mathrm{e}=33$ and 34 [25]. To account for these experimental findings, the following mechanistic model was proposed, supposing the decomposition of UHP in the ion source (scheme 2):

It should be mentioned that (Figure 2A) and (Figure 2B) are quite similar except peaks intensities. This implies that the spectrum of ppt-2 (Figure 2A) is related to a compound similar to urea, such as urea adduct.

Enhancement of 28, 29, 30, $31 \mathrm{~m} / \mathrm{z}$ peaks intensities

It is obvious that the intensities of $28,29,30$, and $31 \mathrm{~m} / \mathrm{z}$ peaks are enhanced in the spectrum of ppt2 (Figure $2 \mathrm{~A}$ ) relative to their intensities in the urea spectrum (Figure 2B). To the knowledge of the author, the assignment of these peaks was not discussed before. It seems that 28, 29, 30, and 31 $\mathrm{m} / \mathrm{z}$ peaks could be assigned to $\mathrm{CO}, \mathrm{CHO}, \mathrm{CH}_{2} \mathrm{O}$ and $\mathrm{CH}_{3} \mathrm{O}$, respectively. This assignment could be explained by the reaction of a carbamoyl radical ion $(44 \mathrm{~m} / \mathrm{z})$ with hydrogen atom donor (H-D) such as hydrogen peroxide (scheme3): 

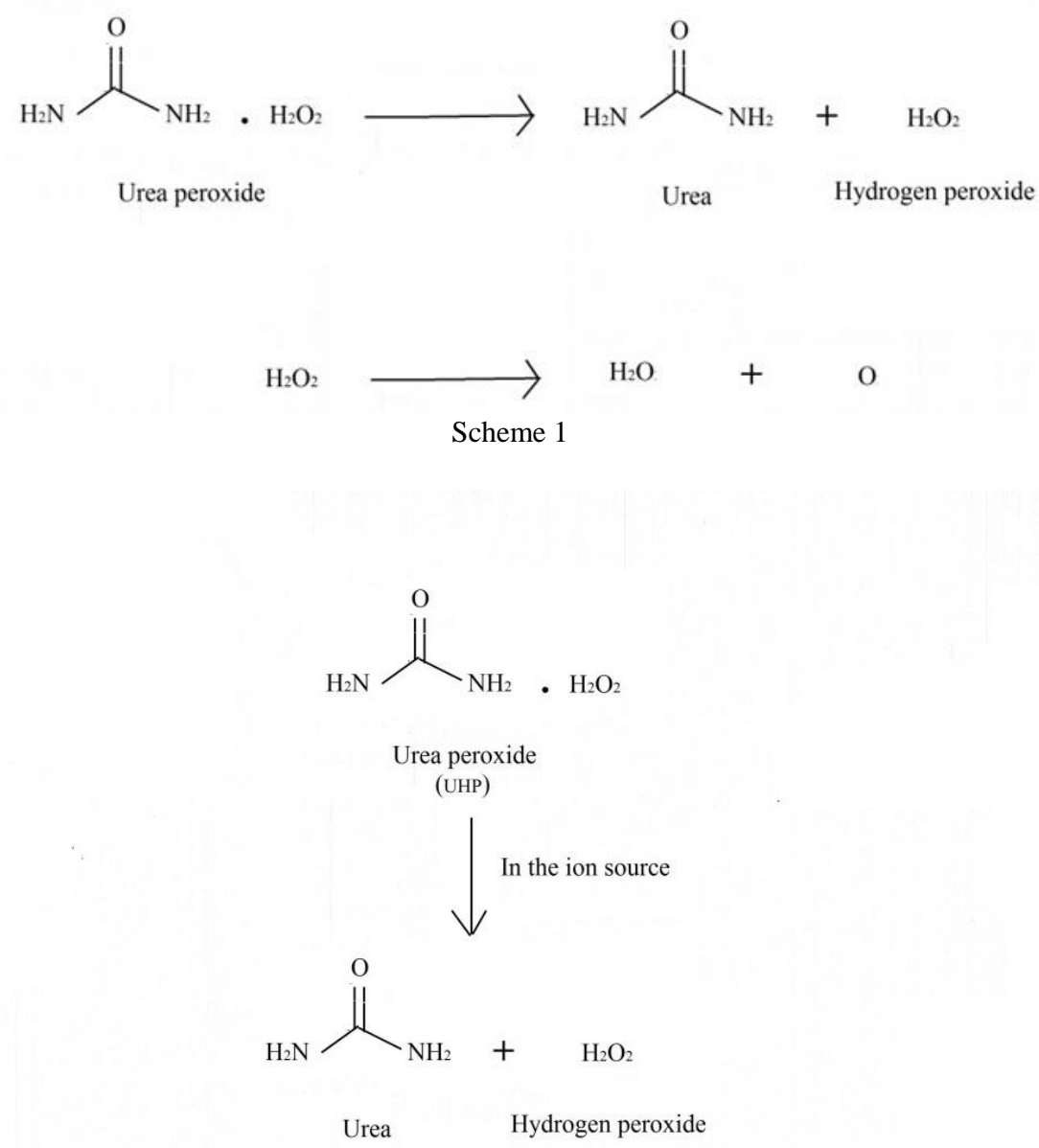

EI

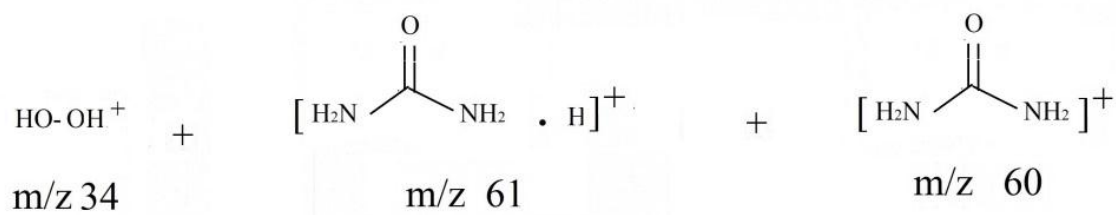

Scheme (2) 


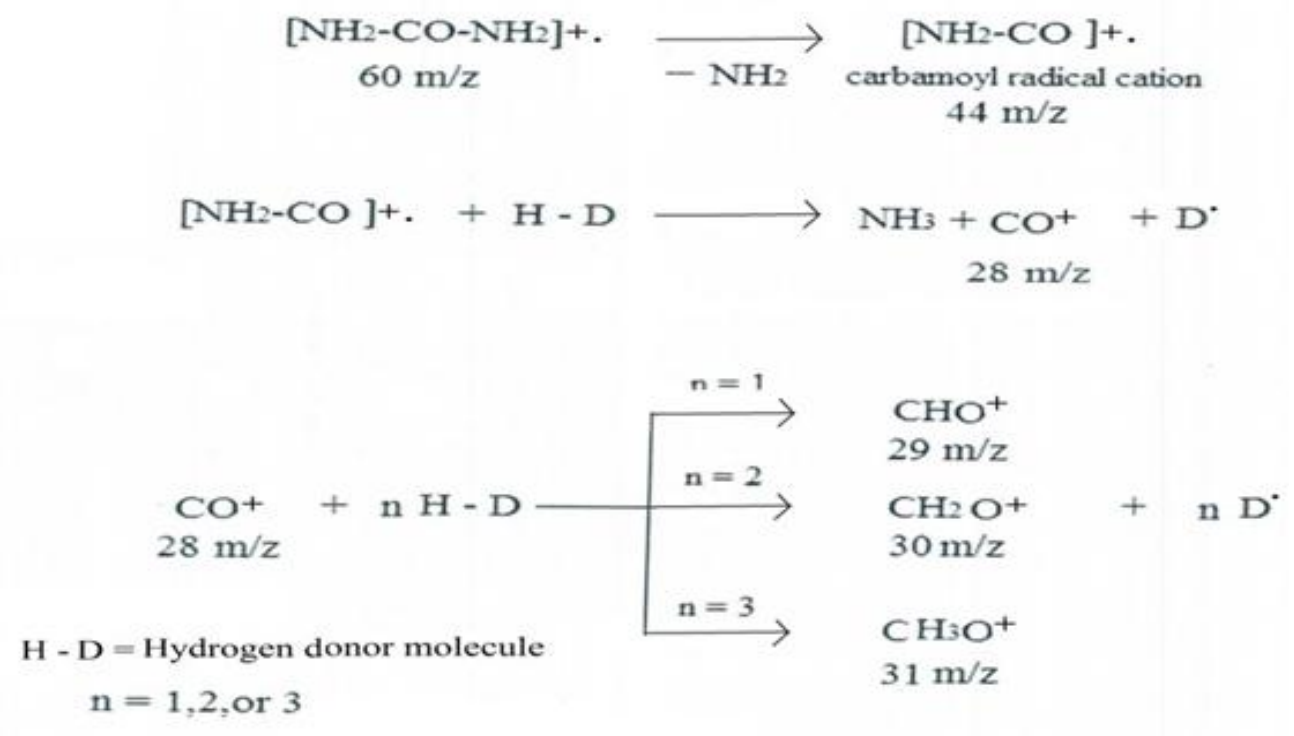

Scheme (3) displays that $\mathrm{CO}^{+}(\mathrm{m} / \mathrm{z}=28)$ could accept one, two, or three, hydrogen atoms from a hydrogen atom donor (such as $\left.\mathrm{H}_{2} \mathrm{O}_{2}\right)$ to form $\mathrm{CHO}^{+}(\mathrm{m} / \mathrm{z}=29), \mathrm{CH}_{2} \mathrm{O}^{+}(\mathrm{m} / \mathrm{z}=30), \mathrm{CH}_{3} \mathrm{O}^{+}(\mathrm{m} / \mathrm{z}=31)$.

\section{NMR}

$1 H-N M R$ of aqueous hydrogen peroxide was studied by Ned et al [26]. They reported that hydrogen peroxide produces a signal around 10-11 ppm, depending upon the solvent molecules and hydrogen peroxide concentration. However, Ohkubo et al. recorded the hydrogen peroxide signal at $<9 \mathrm{ppm}$ [27]. To the knowledge of the author $1 \mathrm{H}-\mathrm{NMR}$ spectrum of UHP has not yet been reported.

The $1 H$-NMR spectra of ppt- 1 and ppt-2 in DMSOd6 are shown in (Figure 3), A and B respectively. Results from a comparative investigation of these spectra indicates the appearance of new signals as well as a downfield shift of urea proton signal. These two new signals at 6.78 and $8.5 \mathrm{ppm}$ are minor but indicative. It was reported that upfield and downfield shift of the protons concerning the $\mathrm{NH}_{2}$ group is due to the formation of new complexes [29]. Therefore, $\mathrm{H}$ - bonding moves amide proton signal downfield [28]. In the free urea ligand, the only peak at $5.6 \mathrm{ppm}$ is assigned to $(4 \mathrm{H} ; 2 \mathrm{NH} 2)$ four protons of two symmetric amino groups [29]. However, in our case the urea proton signal appeared at $5.3 \mathrm{ppm}$ (Figure 3.A), and this could be attributed to the presence of $\mathrm{H}_{2} \mathrm{O}$ in ppt-1 in the form of urea monohydrate (see -EDS section). When comparing the ppt-1 spectrum (Figure 3A) with that of ppt-2 (Figure 3B), it is obvious that, the urea protons signal in (Figure 3.A) (5.3ppm) is downfield shifted $(5.5 \mathrm{ppm})$ in the ppt-2 spectrum (Figure 3.B) suggesting the formation of hydrogen bonding [30]. Moreover, it was stated that $|\Delta \delta|>$ $0.2 \mathrm{ppm}$ is considered as a significant value [31]. In our case the shift of urea protons signal can be attributed to changes in the electronic environment, i.e., an increase in deshielding of the urea protons as a consequence of the H-bonding [32]. Other new signals in the ppt-2 spectrum, at 6.78 and 8.5 ppm are probably due to $\mathrm{H}_{2} \mathrm{O}_{2}$ [27]. This concept is confirmed by the $1 \mathrm{H}-\mathrm{NMR}$ study of acetone and hydrogen peroxide reaction, which includes a similar spectrum [33]. As mentioned above, urea can participate in hydrogen bonding with oxygen atoms which can accept a proton, whereas the nitrogen atoms can donate and accept a proton of $\mathrm{N}-\mathrm{H}$ bonds [18]. Consequently, hydrogen peroxide can play the role of proton donor and urea as proton acceptor and vice, versa. This behavior is similar to that of water, which plays the role of strong acceptor and a relatively weak donor of hydrogen bonds [34]. 


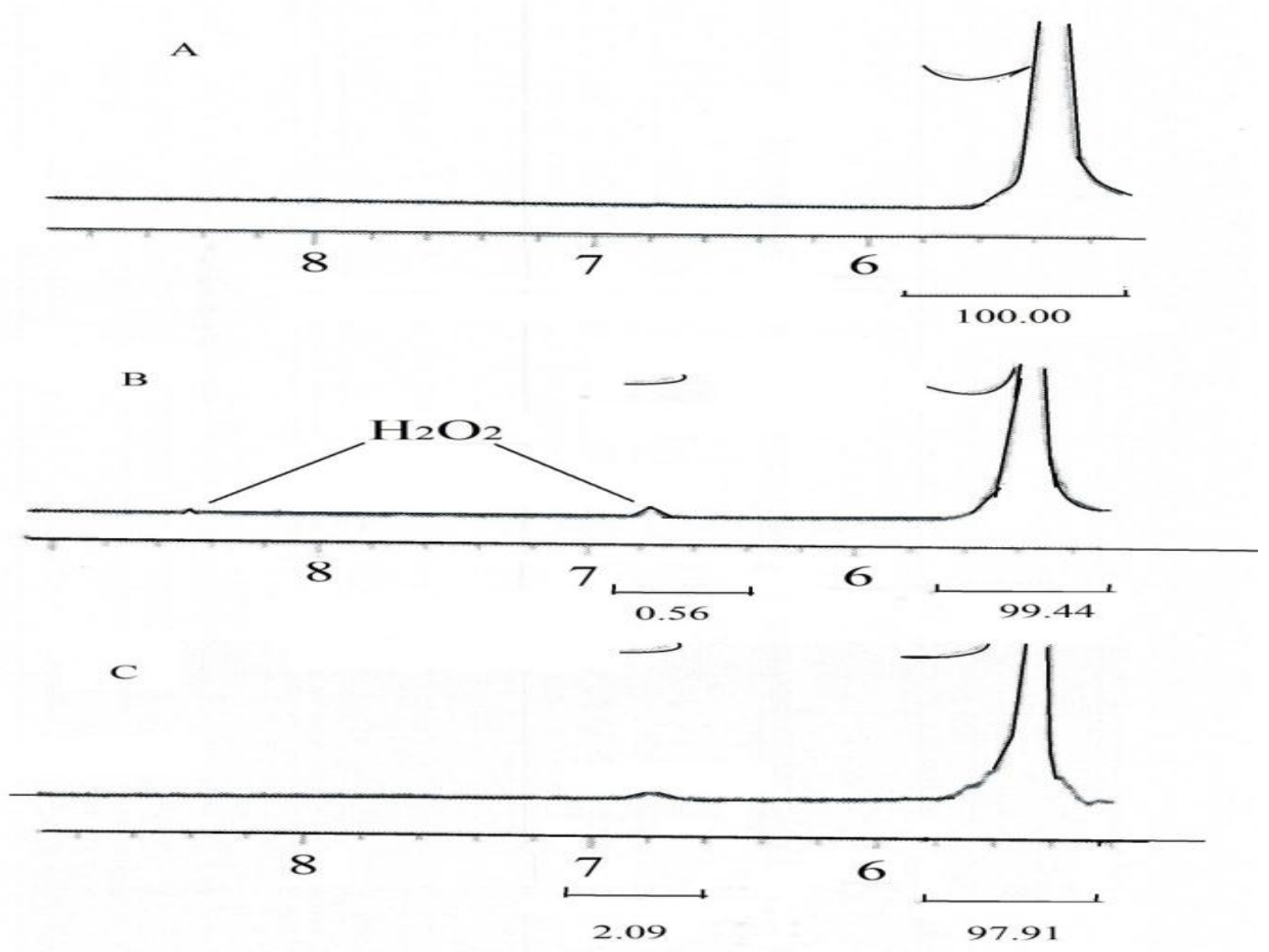

Figure (3) A selected region of the 1H- NMR spectrum (DMSO-d6, $\delta$ ppm) of A- ppt-1, B- ppt-2, C- ppt-2 after D2O shake experiment

It can be concluded from NMR H-D exchange experiment that, if a signal disappears immediately after addition of $\mathrm{D}_{2} \mathrm{O}$, it is likely that the corresponding proton is not involved in a H-bond and vice versa [30]. In our case, upon shaking ppt2 sample with $\mathrm{D}_{2} \mathrm{O}$, the signal at $8.5 \mathrm{ppm}$ declines and disappears from the spectrum, on the other hand the signal at $6.78 \mathrm{ppm}$ persists but become smaller (Figure 3C). Therefore, it is likely that the later signal $(6.78 \mathrm{ppm})$ corresponds to protons which participate in a stable $\mathrm{H}$-bond [30]. These protons could be related to $\mathrm{H}_{2} \mathrm{O}_{2}$ (proton donor). On the other hand, the signal at $8.5 \mathrm{ppm}$, which disappeared after $\mathrm{D}_{2} \mathrm{O}$ shake, can be assigned to free $\mathrm{H}_{2} \mathrm{O}_{2}$, which is present at a smaller ratio. Table (2) shows the effect of $\mathrm{D}_{2} \mathrm{O}$ on the signal integration values at 5.5 and $6.78 \mathrm{ppm}$ of ppt-1 and ppt-2 $1 \mathrm{H}-\mathrm{NMR}$ spectra. The data presented in Table (2) indicate that upon addition of $\mathrm{D}_{2} \mathrm{O}$ to ppt-2 sample signal integration values at $6.78 \mathrm{ppm}$ increased, on the other hand that for signal at 5.5 ppm decreased. This observation can be attributed to that, the signal at $5.5 \mathrm{ppm}$ is related to protons easily exchanged with deuterons relative to the protons of $6.78 \mathrm{ppm}$ signal. Therefore, it is likely that the later signal $(6.78 \mathrm{ppm})$ corresponds to protons which participate in a stable H-bond [30].

Table (2) The effect of $\mathrm{D}_{2} \mathrm{O}$ on the signal integration values at 5.5 and $6.78 \mathrm{ppm}$

\begin{tabular}{|c|c|c|}
\hline $\begin{array}{c}\text { Solvent } \\
\text { composition } \\
\text { of the ppt-2 } \\
\text { sample }\end{array}$ & $\begin{array}{c}\text { Signal } \\
\text { integration } \\
\text { values at } \\
5.5 \mathrm{ppm}\end{array}$ & $\begin{array}{c}\text { Signal } \\
\text { integration } \\
\text { values at } \\
6.78 \mathrm{ppm}\end{array}$ \\
\hline $\begin{array}{l}\text { DMSO-d6 } \\
\text { (Figure3B) }\end{array}$ & 99.4 & 0.56 \\
\hline $\begin{array}{c}\text { DMSO-d6 + } \\
\mathrm{D}_{2} \mathrm{O} \\
\text { (Figure } 3 \mathrm{C} \text { ) }\end{array}$ & 97.91 & 2.09 \\
\hline
\end{tabular}

Raman spectroscopic studies

Raman spectroscopy is considered a powerful technique for the detection of changes formed 
upon hydrogen bond formation. As a matter of fact, the dipole moment, $\mathrm{P}$, induced in a molecule by an external electric field is proportional to the intensity of this field, E

$$
\mathbf{P}=\boldsymbol{\alpha} \mathbf{E}
$$

Where, the proportionality constant $\boldsymbol{\alpha}$ is the polarizability of the molecule. It is well known that Raman scattering occurs because a molecular vibration can change the polarizability of the molecule. This change is described by the polarizability derivative, $\mathrm{d} \boldsymbol{\alpha} / \mathrm{dQ}$, where $\mathrm{Q}$ is the normal coordinate of the vibration i.e., the amplitude of the nuclear motion. Moreover, the scattering intensity is proportional to the square of the polarizability derivative $|\delta \boldsymbol{\alpha} / \delta \mathrm{Q}|^{2} \quad$ [35]. It is worth mentioning that a previus study referred to that, ground state polarization and dipole moment of the UHP are higher than urea due to the presence of $\mathrm{H}$-bonded $\mathrm{H}_{2} \mathrm{O}_{2}$ (Table 3) [ 36].

\section{Table (3) Dipole moment of UHP and urea}

\begin{tabular}{|l|c|}
\hline Compound & $\begin{array}{l}\text { Dipole } \\
\text { moment }\end{array}$ \\
\hline$\left(\mathrm{NH}_{2}\right)_{2} \mathrm{CO} \ldots \mathrm{HOOH}$ & 4.8 \\
\hline $\mathrm{OC}\left(\mathrm{NH}_{2}\right) \mathrm{NH}_{2} \ldots \mathrm{O}(\mathrm{H}) \mathrm{OH}$ & 6.3 \\
\hline$\left(\mathrm{NH}_{2}\right)_{2} \mathrm{CO}$ & $4.56[37]$ \\
\hline
\end{tabular}

Moreover, a preliminary study reveals that second - order nonlinear optical activity (NLO) behavior of UHP is better than urea due to self-assembly of two or more molecular components in the former. Accordingly, the degree of charge separation in UHP increases due to the presence of hydrogen bonded $\mathrm{H}_{2} \mathrm{O}_{2}$ [7]. These findings are important to take into consideration when studying data obtained from our Raman spectra. As a matter of fact, the Raman spectrum of hydrogen peroxide is mainly characterized by O-O stretch between 800 and $1000 \mathrm{~cm}^{-}{ }^{1}$ [33]. Moreover, O-H Vibration of hydrogen peroxide is characterized by a peak at $3593 \mathrm{~cm}^{-1}$ (OH-stretch) [33]. To the best of our knowledge, Raman spectral study of UHP has not been yet studied. On the other hand, the Raman spectrum of crystalline urea was studied by several authors $[19,38]$, as well as urea aqueous solutions [39].

From these considerations it seems fair to expect that the Raman spectrum of UHP can be differentiated from that of urea by: (a) Higher intensity of particular peaks due to the higher polarization of UHP relative to urea [40]. (b) Appearance of new peaks such as O-H stretching vibration above $3200 \mathrm{~cm}^{-1}$ as well as a peak due to $\mathrm{O}-\mathrm{O}$ stretching vibration in the range $800-$ $1000 \mathrm{~cm}^{-1}$ due to the engagement of $\mathrm{H}_{2} \mathrm{O}_{2}$ in the urea adduct. (c) Blue and red shifts of bands due to hydrogen bonding between urea and hydrogen peroxide.

\section{Raman spectral studies on solid residues (SR)}

The Raman spectra of ppt-1 and ppt-2 at 298K are shown in Figure (4) A and B, respectively. Table (4) lists the absorption bands and their assignments of ppt-1 and ppt-2 spectra. Accordingly, ppt-2 spectrum shows certain characteristic differences from that of ppt-1. These differences are qualitative (shift of the characteristic band maxima), as well as quantitative (different intensities of the corresponding bands and a variation in the shape of some bands). The variation in both intensity, and position of bands on passing from ppt-1 to ppt2 spectra, can be used as an indication for hydrogen-bonding interactions [41] between urea and other species.

\section{Red and blue shifts}

Table (4) shows the bands frequency $\left(\mathrm{cm}^{-1}\right)$ of ppt1 and ppt-2 spectra, the values of red and blue shift $\left(\Delta \mathrm{cm}^{-1}\right)$ as well as the proposed assignments for each band. 

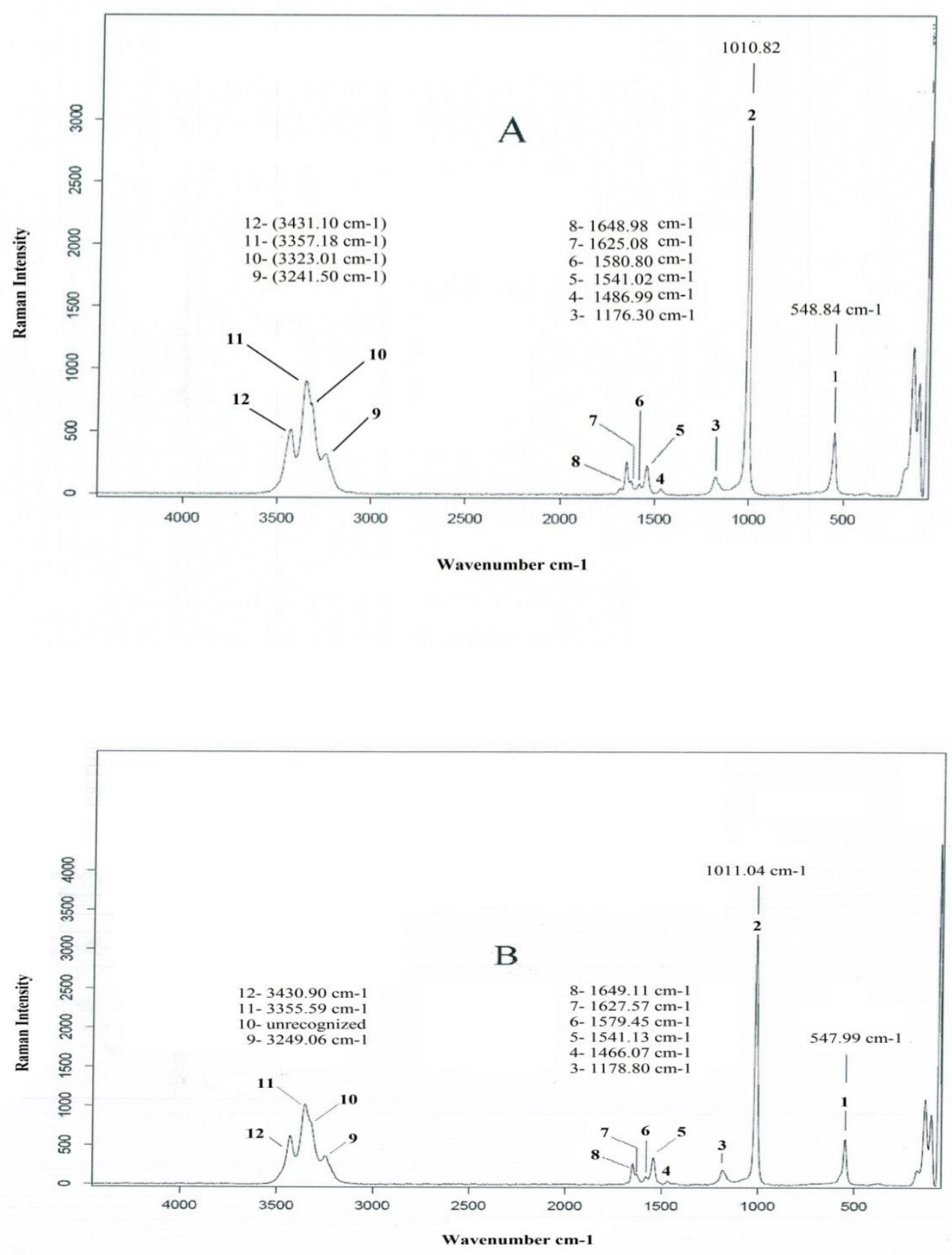

Figure (4) Raman spectra of ppt-1 (A) and ppt-2 (B) 
Table (4) Band shift $\left(\Delta \mathrm{cm}^{-1}\right)$ determination from comparison of ppt-1 and ppt-2 Raman spectra Figure (4A and B) respectively

\begin{tabular}{|c|c|c|c|c|c|}
\hline Band No, & $\begin{array}{l}\text { Spectrum: A } \\
\text { of ppt-1 }\end{array}$ & $\begin{array}{l}\text { Spectrum:B } \\
\text { of ppt-2 }\end{array}$ & $\begin{array}{c}\text { Band } \\
\text { shift } \\
\left(\Delta \mathbf{c m}^{-1}\right)\end{array}$ & Band assignment & Reference \\
\hline 1 & 548.84 & 547.99 & -0.85 & $\begin{array}{l}\mathrm{NCO} \text { and NCN } \\
\text { bending modes }\end{array}$ & 19 \\
\hline 2 & 1010.82 & 1011.04 & +0.22 & $\begin{array}{l}\text { NCN symmetric } \\
\text { stretching modes }\end{array}$ & 19 \\
\hline 3 & 1176.30 & 1178.80 & +2.50 & $\begin{array}{c}\mathrm{NH} 2 \\
\text { rocking vibrations } \\
\text { modes } \\
\end{array}$ & 19 \\
\hline 4 & 1466.99 & 1466.07 & -0.92 & $\begin{array}{l}\text { antisymmetric } \\
\text { NCN } \\
\text { stretching mode }\end{array}$ & 19 \\
\hline 5 & 1541.02 & 1541.13 & +0.11 & $\begin{array}{l}\mathrm{NH} 2 \text { bending } \\
\text { mode }\end{array}$ & 19 \\
\hline 6 & 1580.80 & 1579.45 & -1.35 & $\begin{array}{c}\text { stretching modes } \\
\text { of hydrogen } \\
\text { bonded } \mathrm{C}=\mathrm{O} \\
\text { group. }\end{array}$ & 19 \\
\hline 7 & 1625.06 & 1627.57 & +2.51 & $\begin{array}{c}\mathrm{H} 2 \mathrm{O} \\
\text { bending modes }\end{array}$ & 55 \\
\hline 8 & 1648.98 & 1649.11 & +0.13 & $\begin{array}{c}\text { stretching modes } \\
\text { of the free } \mathrm{C}=\mathrm{O} \\
\text { group. }\end{array}$ & 19 \\
\hline 9 & 3241.50 & 3249.06 & +7.56 & $\mathrm{~N}-\mathrm{H}$ stretching & 19 \\
\hline 10 & $\begin{array}{l}\text { Unidentified } \\
\text { peak } \\
\text { maximum } \\
\text { (shoulder) }\end{array}$ & $\begin{array}{c}\text { Unidentified } \\
\text { peak } \\
\text { maximum } \\
\text { (shoulder) }\end{array}$ & - & $\begin{array}{l}\mathrm{N}-\mathrm{H} \text { stretching } \\
\text { anti-symmetric } \\
\text { and/or symmetric }\end{array}$ & 19 \\
\hline 11 & 3357.18 & 3355.59 & -1.59 & $\begin{array}{c}\mathrm{N}-\mathrm{H} \text { stretching } \\
\text { anti-symmetric } \\
\text { and/or symmetric }\end{array}$ & 19 \\
\hline 12 & 3431.10 & 3430.90 & -0.20 & $\begin{array}{l}\mathrm{N}-\mathrm{H} \text { stretching } \\
\text { anti-symmetric }\end{array}$ & 56,19 \\
\hline
\end{tabular}

It had been reported [42] that some Raman spectral bands of proton-donor molecules exhibit a blueshift, whereas for the proton-acceptor molecules a red-shift was exhibited. Accordingly, in our case minor red or blue bands shifts were observed for all the bands in ppt-2 spectrum, relative to their position in that of ppt-1. It should be mentioned that similar minor values of Raman band shifts were reported in literature [43]. Urea can behave as a proton donor,via the $\mathrm{N}$ atoms, and a proton acceptor via the $\mathrm{O}$ and $\mathrm{N}$ atoms [18]. The bands between 3241 and $3431 \mathrm{~cm}^{-1}$ were attributed to the 
symmetric and antisymmetric N-H stretching modes of urea [19]. In our case, the red shifted bands, 10-12, can be assigned to $\mathrm{N}-\mathrm{H}$ stretch vibration of urea in which the $\mathrm{N}$ atom behaves as a proton acceptor. Whereas, the blue shifted band 9 could be assigned to $\mathrm{N}-\mathrm{H}$ stretch vibration of urea in which $\mathrm{N}$ atom behaves as a proton-donor [42]. Moreover, bands 6 (red shifted) and 8 (blue shifted) correspond to stretching modes of hydrogen bonded and free $\mathrm{C}=\mathrm{O}$ group in urea molecules, respectively [19].

As mentioned above, the presence of $\mathrm{H}_{2} \mathrm{O}_{2}$ is indicated by the presence of bands in the range 800 $-1000 \mathrm{~cm}^{-1}$ for O-O stretching mode [33] and the range $3000-3600 \mathrm{~cm}^{-1}$ for $\mathrm{OH}$ stretching mode [33,44]. But in our case $\mathrm{H}_{2} \mathrm{O}_{2}$, if present, will be engaged in the hydrogen bonding adduct with urea. Consequently, these bands will be red or blue shifted according to the $\mathrm{H}_{2} \mathrm{O}_{2}$ role in hydrogen bonding [42]. Therefore, the band due to O-O stretching mode could be blue shifted $\left(\mathrm{H}_{2} \mathrm{O}_{2}\right.$ is almost a proton donor) due to an adduct formation and consequently may be masked or overlapped by the band centered in the range $1010-1011 \mathrm{~cm}^{-1}$. Unfortunately, the $\mathrm{OH}$ stretching mode range in our spectra is occupied by the $\mathrm{NH}$ stretching vibrational bands of urea, which means that, the band due to $\mathrm{OH}$ stretching mode of $\mathrm{H}_{2} \mathrm{O}_{2}$, if present, will be masked by the $\mathrm{NH}$ stretching bands.

Variation of the relative band intensity ratios between of ppt-1 and ppt-2 Raman spectra

(Figure $4 A$ and $B$ respectively)

A comparison of the relative intensity (height) of bands in both ppt-1 and ppt-2 spectra (Figure 4A and $\mathrm{B}$ respectively) is shown in Table (5). Band-2 height was used as the reference to determine the relative Raman intensity. It is worth to mention that the peak heights were measured from the peak apex to the intersection with the artificial baseline [45].

Table (5) Relative bands intensities (heights) in the Raman spectra of ppt-1 and ppt-2

(Figure 4A and $B$ respectively)

\begin{tabular}{|c|l|c|c|c|c|}
\hline \multicolumn{2}{|c|}{ ppt-1 spectrum } & \multicolumn{3}{c|}{ ppt-2 spectrum } \\
\hline $\begin{array}{c}\text { Band } \\
\text { number }\end{array}$ & $\begin{array}{l}\text { Position } \\
\left(\mathbf{c m}^{-1}\right)\end{array}$ & $\begin{array}{l}\text { Bands heights } \\
\text { relative to band-2 } \\
\text { height }\end{array}$ & $\begin{array}{l}\text { Band } \\
\text { number }\end{array}$ & $\begin{array}{l}\text { Position } \\
\left(\mathbf{c m}^{-1}\right)\end{array}$ & $\begin{array}{l}\text { Bands heights } \\
\text { relative } \begin{array}{r}\text { to } \\
\text { band-2 height }\end{array}\end{array}$ \\
\hline 1 & 548.84 & 0.168 & 1 & 547.99 & 0.184 \\
\hline 2 & 1010.82 & 1.000 & 2 & 1011.04 & 1.000 \\
\hline 3 & 1176.30 & 0.052 & 3 & 1178.8 & 0.060 \\
\hline 4 & 1466.99 & 0.024 & 4 & 1466.07 & 0.014 \\
\hline 5 & 1541.02 & 0.079 & 5 & 1541.13 & 0.113 \\
\hline 6 & 1580.80 & 0.031 & 6 & 1579.45 & 0.035 \\
\hline 7 & 1625.06 & 0.039 & 7 & 1627.57 & 0.043 \\
\hline 8 & 1648.98 & 0.084 & 8 & 1649.11 & 0.085 \\
\hline 9 & 3241.50 & 0.110 & 9 & 3249.06 & 0.113 \\
\hline 10 & 3323.01 & - & 10 & $\begin{array}{c}\text { mnidentified peak } \\
\text { (shoulder) }\end{array}$ & \\
\hline 11 & 3357.18 & 0.293 & 11 & 3355.59 & 0.319 \\
\hline 12 & 3431.10 & 0.173 & 12 & 3430.90 & 0.190 \\
\hline
\end{tabular}



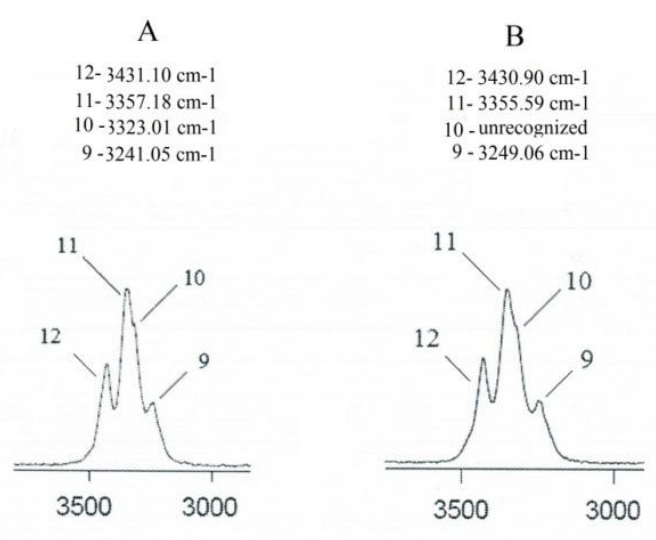

Figure (5) Overlapped bands in the range $3000-3500 \mathrm{~cm}^{-1}$ in Raman spectra: (A) ppt-1 spectrum and (B) ppt-2 spectrum

It is apparent from Table (5) that there are relative intensity variations for all bands on passing from ppt-1 to ppt-2 spectra. In general, the band intensities of ppt-2 are higher than those of ppt-1, especially $>3000 \mathrm{~cm}^{-1}$. Not only the intensities changed but also the shape of bands in this range (Figure 5).

It is worth mentioning that changes in the shape and intensity of the bands in the Raman spectra provides an evidence for complex formation, including the formation of H-bonding [41].

\section{Raman spectral studies on UAS}

The Raman spectra of urea were studied in aqueous solutions by several authors [39, 46]. The spectrum of crystalline urea shows certain characteristic differences when compared with that of its aqueous solutions. Red and blue shifts, as well as intensity changes were observed on passing from the crystal to aqueous solution. These differences are, of course, due to the large influence of the highly polar solvent on the solute [38]. The Raman spectra of unirradiated (UNS) and irradiated (IRS) 6M UAS are shown in Figure (6). The proposed band assignments are given in Table (6).

Figureure (7) shows a selected region (500 - 1000 $\mathrm{cm}^{-1}$ ) of the Raman spectra of unirradiated (UNS) (A), and irradiated (IRS) (B) 6M UAS. When the spectra in Figure (7 A and B), are compared, it can be seen that the shape and the location of overlapped bands 2and 3 array (gp2-3) are changed. These bands can be assigned to the out of plane $\mathrm{NH}_{2}$ bending [47]. The band due to $\mathrm{NH}$ bending is red shifted with the increase in intensity upon complexation [48]. That could be attributed to the fact that strong hydrogen bonding leads to covalent bond weakness, and consequently its stretching frequency will be red shifted [49, 50]. Therefore, in our case, the variation of (gp2-3) in both shape and location (red shift) can be assigned to the participation of urea in a complex such as a hydrogen bonding adduct [41].

As mentioned earlier, the presence of $\mathrm{H}_{2} \mathrm{O}_{2}$ is indicated by the presence of bands in the range 800 $-1000 \mathrm{~cm}^{-1}$ for O-O stretching mode [33] and in the range $3000-3600 \mathrm{~cm}^{-1}$ for $\mathrm{OH}$ stretching mode $[33,44]$. Therefore, in Figure (7B) the band due to $\mathrm{O}-\mathrm{O}$ stretching is assumed to be masked by bands2 and -3 region. In addition, the overlapped bands in the range $3000-3600 \mathrm{~cm}^{-1}$ are due to $\mathrm{N}-\mathrm{H}$ and $\mathrm{O}-\mathrm{H}$ stretching vibration of urea and water respectively [44]. Moreover, the hydroxyl stretching modes of strong hydrogen bonds occur below $3420 \mathrm{~cm}^{-1}$ [51]. Therefore, in our case, if $\mathrm{H}_{2} \mathrm{O}_{2}$ is present and hydrogen bonded to urea, its corresponding hydroxyl stretching band will be included in (gp7-9). It is worthy of notice that a change could be observed in the shape and location of this array of bands (Figure $8 \mathrm{~A}$ and $\mathrm{B}$ ). This change can indicate the presence of a new band (or bands).

The band intensities and locations (shift) in both spectra of unirradiated (UNS) (Figure $6 \mathrm{~A}$ ), and irradiated (IRS) (Figure 6 B) 6M urea aqueous solution will be discussed in detail subsequently.

\section{Red and blue shifts}

Blue and red shifts were observed for all bands in the Raman spectrum of IRS relative to their positions in URS spectrum. In a hydrogen bonding system, Raman spectral bands of proton-donor molecules present a blue-shift, whereas for the proton-acceptor molecules, they present a red-shift $[39,47]$. It should be mentioned that similar minor values of band shifts were reported in literature ${ }^{[43]}$. Bands frequencies and attributions of UNS and IRS spectra, as well as the values of red and blue shift for each band are shown in Table (6) 

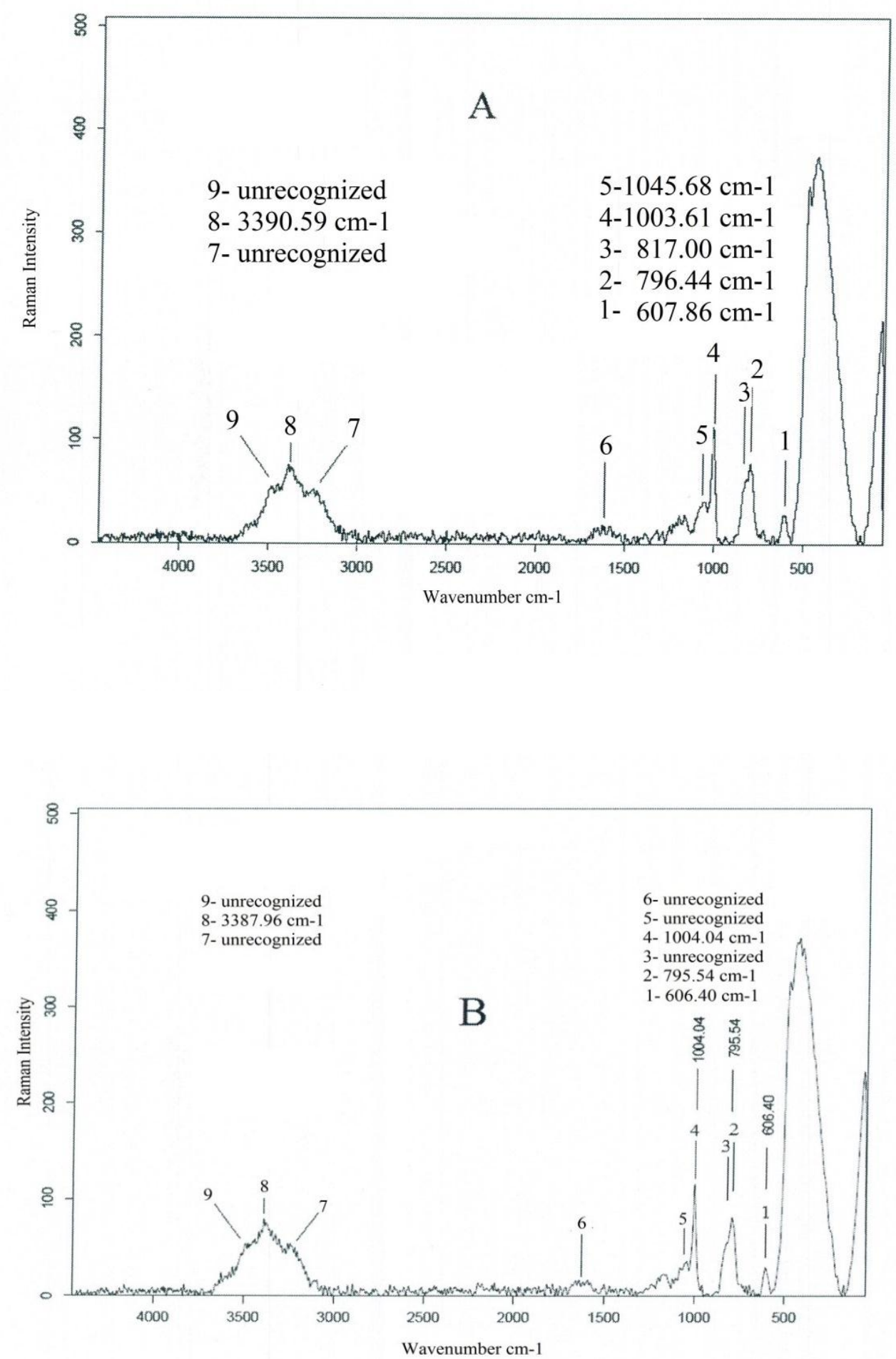

Figure (6) Raman spectra of (UNS) and (IRS) (B) 
3. $817.00 \mathrm{~cm}-1$
2. $796.44 \mathrm{~cm}-1$

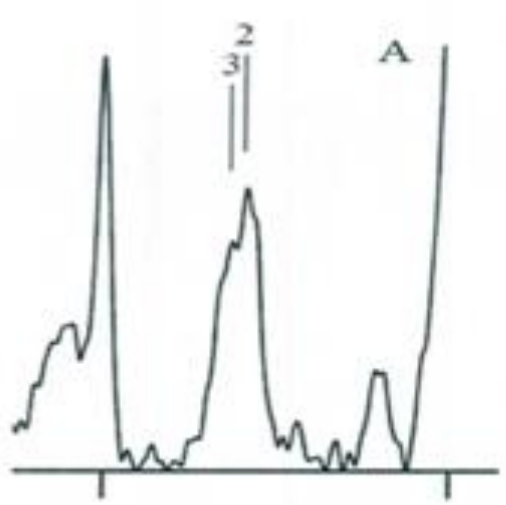

$1000 \quad 500$
3. unresogaized
2. $795 \leqslant 4 \mathrm{~cm}-1$

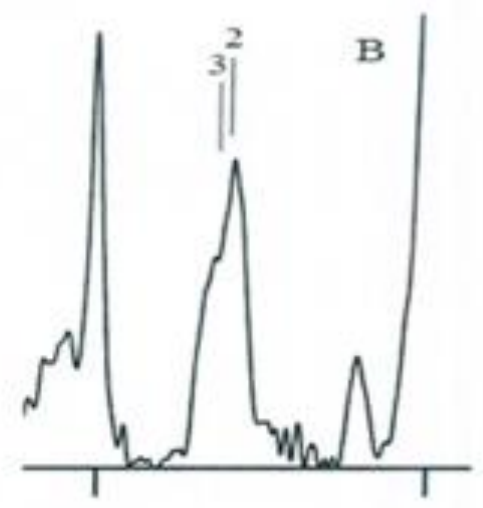

1000

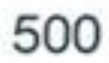

Figure (7) A selected region $\left(500-1000 \mathrm{~cm}^{-1}\right)$ of the Raman spectra of unirradiated (UNS) (A), and irradiated (IRS) (B) 6M UAS

$3390.59 \mathrm{~cm}-1$
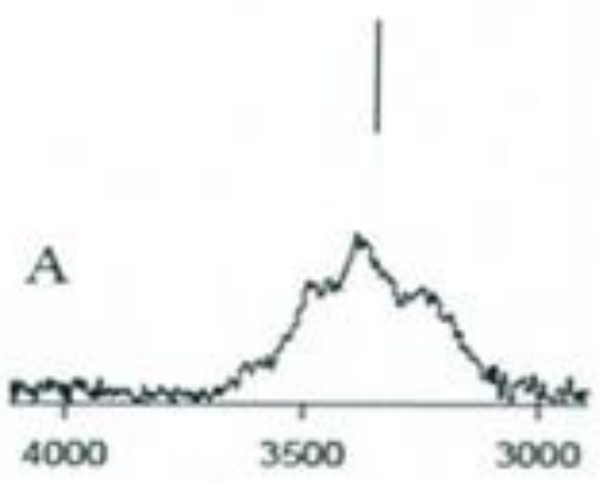

$3387.96 \mathrm{~cm}-1$

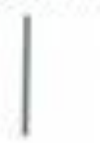

(Figure 8) Overlapped bands (gp7-9) in the range $3000-3500 \mathrm{~cm}^{-1}$ in Raman spectra of unirradiated (UNS) (A), and irradiated (IRS) (B) 6M UAS 
Table (6) Band shift $\left(\Delta \mathrm{cm}^{-1}\right)$ determination from comparison of the (UNS), and (IRS) Raman spectra (Figure 6A and $B$ respectively)

\begin{tabular}{|c|c|c|c|c|c|}
\hline $\begin{array}{l}\text { Band } \\
\text { No, }\end{array}$ & $\begin{array}{l}\text { Spectrum: A } \\
\text { of UNS }\end{array}$ & $\begin{array}{l}\text { Spectrum: } \\
\text { B of IRS }\end{array}$ & $\begin{array}{l}\text { Band } \\
\text { shift } \\
\left(\Delta \mathrm{cm}^{-1}\right)\end{array}$ & Possible Assignment & Reference \\
\hline 1 & 607.86 & 606.40 & -1.46 & 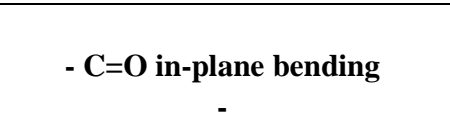 & 47 \\
\hline 2 & 796.44 & 795.54 & -0.90 & NH2 twisting & 47 \\
\hline 3 & 817.00 & 820.50 & +3.50 & $\mathrm{NH}_{2}$ twisting & 47 \\
\hline 4 & 1003.61 & 1004.04 & +0.43 & $\begin{array}{c}\text { NCN Symmetric stretching } \\
\text { vibration }\end{array}$ & 19 \\
\hline 5 & $\begin{array}{c}\text { Unidentified } \\
\text { peak } \\
\text { maximum }\end{array}$ & $\begin{array}{l}\text { Unidentified } \\
\text { peak } \\
\text { maximum }\end{array}$ & - & $\begin{array}{l}\mathrm{NH}_{2} \text { symmetric rocking } \\
\text { vibration and/or } \mathrm{C}-\mathrm{N} \\
\text { asymmetric stretching }\end{array}$ & 57 \\
\hline 6 & $\begin{array}{c}\text { Unidentified } \\
\text { peak } \\
\text { maximum } \\
\end{array}$ & $\begin{array}{c}\text { Unidentified } \\
\text { peak } \\
\text { maximum } \\
\end{array}$ & - & $\begin{array}{l}\text { Free and hydrogen bonded } \mathrm{C}=\mathrm{O} \\
\text { stretching vibration } \\
\text { and/or } \mathrm{NH}_{2} \text { bending vibration }\end{array}$ & 19 \\
\hline 7 & $\begin{array}{c}\text { Unidentified } \\
\text { peak } \\
\text { maximum }\end{array}$ & $\begin{array}{c}\text { Unidentified } \\
\text { peak } \\
\text { maximum } \\
\end{array}$ & - & $\begin{array}{c}\text { Symmetric and /or Anti- } \\
\text { symmetric NH and /or OH } \\
\text { stretching vibration }\end{array}$ & 19 \\
\hline 8 & 3390.54 & 3387.96 & -2.58 & $\begin{array}{c}\text { Symmetric and /or Anti- } \\
\text { symmetric NH and /or } \mathrm{OH} \\
\text { stretching vibration }\end{array}$ & 19 \\
\hline 9 & $\begin{array}{c}\text { Unidentified } \\
\text { peak } \\
\text { maximum }\end{array}$ & $\begin{array}{l}\text { Unidentified } \\
\text { peak } \\
\text { maximum }\end{array}$ & - & $\begin{array}{c}\text { Symmetric and /or Anti- } \\
\text { symmetric NH and /or } \mathrm{OH} \\
\text { stretching vibration }\end{array}$ & 19 \\
\hline
\end{tabular}

Variation of the relative band intensity ratios between of UNS and IRS Raman spectra (Figure $6 A$ and $B$ respectively)

The band intensities (relative heights) of all bands of UNS and IRS spectra (Figure 6) are presented in Table (7). The height of band- 4 was used as the reference for the determination of bands relative intensities (height). It is worthy of notice that the peak heights were measured from the peak apex to the intersection with the artificial baseline [45].

When the data in Table (7) are compared it can be seen, generally, that, there is an increase in the Raman band intensities of IRS spectrum (Figure 6 B) relative to that of UNS (Figure $6 \mathrm{~A}$ ).
During $\gamma$ - radiolysis of water, hydrogen peroxide is mainly formed by the following reactions [52,54]:

$$
\begin{aligned}
& 2 \mathrm{OH} \rightarrow \mathrm{H}_{2} \mathrm{O}_{2} \\
& 2 \mathrm{HO}_{2} \rightarrow \mathrm{H}_{2} \mathrm{O}_{2}+\mathrm{O}_{2}
\end{aligned}
$$

Meanwhile, the produced hydrogen peroxide could be consumed via the reaction with $\mathrm{OH}, \mathrm{H}, \mathrm{e}_{\mathrm{aq}}$ :

$$
\begin{gathered}
\mathrm{OH}+\mathrm{H}_{2} \mathrm{O}_{2} \rightarrow \mathrm{H}_{2} \mathrm{O}+\mathrm{HO}_{2} \\
\mathrm{H}+\mathrm{H}_{2} \mathrm{O}_{2} \rightarrow \mathrm{H}_{2} \mathrm{O}+\mathrm{OH} \\
{ }_{\text {eaq }}^{-}+\mathrm{H}_{2} \mathrm{O}_{2} \rightarrow \mathrm{OH}^{-}+\mathrm{OH}
\end{gathered}
$$

On the other hand urea tends to react with $\mathrm{OH}, \mathrm{H}$, $\mathrm{e}_{\mathrm{aq}}$ [53] (Scheme 4);

Urea enhancement of hydrogen peroxide : formation 


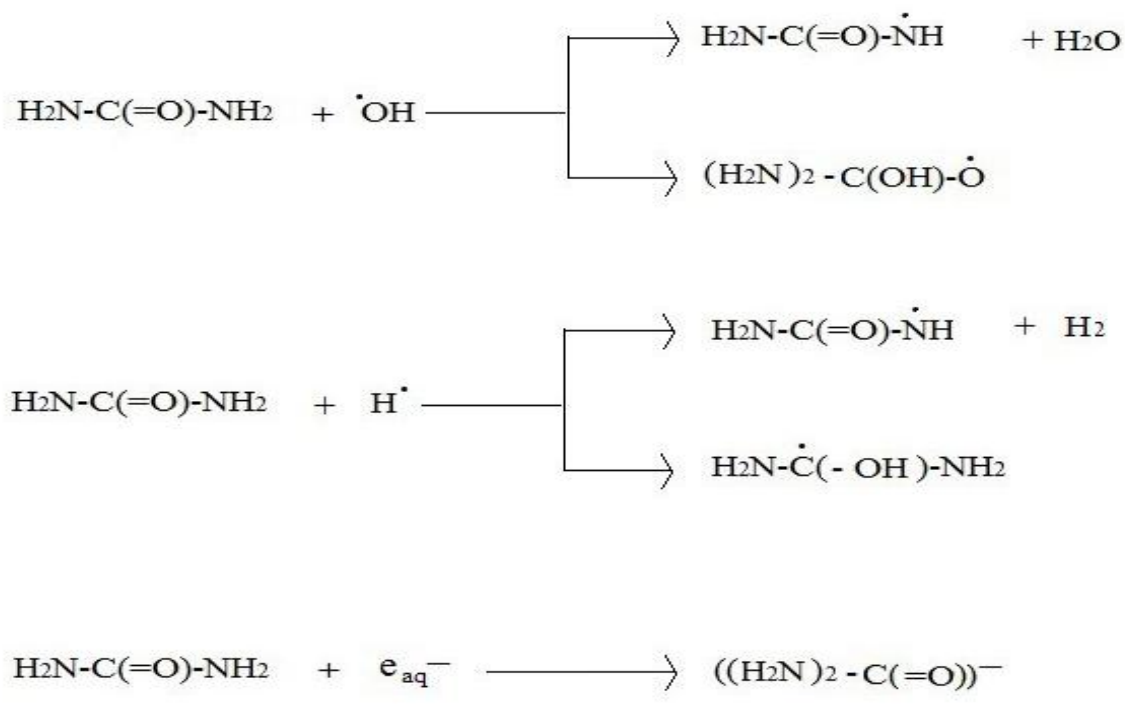

Scheme (4)

Radicals produced from the reaction of urea with $\mathrm{OH}$ could disproportionate reforming urea [53]: $\mathrm{H}_{2} \mathrm{~N}-\mathrm{C} \cdot(-\mathrm{OH})-\mathrm{NH}_{2}+\mathrm{NH}_{2}-\mathrm{C}(=\mathrm{O})-\mathrm{NH}$ $\longrightarrow 2 \mathrm{NH}_{2}-\mathrm{C}(=\mathrm{O})-\mathrm{NH}_{2}$

$2\left(\mathrm{H}_{2} \mathrm{~N}\right)_{2}-\mathrm{C}(-\mathrm{OH})-\mathrm{O} \longrightarrow \mathrm{NH}_{2}-\mathrm{C}(=\mathrm{O})-\mathrm{NH}_{2}+$ $\left(\mathrm{NH}_{2}\right)_{2}-\mathrm{C}-(\mathrm{O})_{2}+\mathrm{H}_{2} \mathrm{O}$

Consequently, it was reported that the major features of the irradiation of urea in aqueous solutions were its low reactivity and its reformation during irradiation, specially, in deaerated condition [53].

Table (7) Relative band heights in the spectrum of (UNS), and (IRS)

\begin{tabular}{|c|c|c|c|}
\hline \multicolumn{2}{|c|}{ UNS spectrum } & \multicolumn{2}{c|}{ IRS spectrum } \\
\hline $\begin{array}{c}\text { Band } \\
\text { number }\end{array}$ & $\begin{array}{c}\text { Bands } \\
\text { heights } \\
\text { relative to } \\
\text { band (4) } \\
\text { height }\end{array}$ & $\begin{array}{c}\text { Band } \\
\text { number }\end{array}$ & $\begin{array}{c}\text { Bands heights } \\
\text { relative to } \\
\text { band (4) height }\end{array}$ \\
\hline 1 & 0.24 & 1 & 0.26 \\
\hline 2 & 0.68 & 2 & 0.69 \\
\hline 3 & 0.55 & 3 & 0.47 \\
\hline 4 & 1.00 & 4 & 1.00 \\
\hline 8 & 0.68 & 8 & 0.69 \\
\hline
\end{tabular}

\section{Conclusion}

The present work reports the first investigation concerned with the possibility of UHP formation upon $\gamma$ - irradiation of UAS. EDS data indicate that the oxygen content of ppt- 2 is greater than that of ppt -1 . This observation indicates that, upon radiolysis of UAS an oxygen-rich compound is formed. Accordingly, it is required to answer a question; could this oxygen-rich compound be urea peroxide?. Mass spectrum of ppt-2 evinces the base peak at $\mathrm{m} / \mathrm{z} 16\left(\mathrm{O}^{+}\right)$, as well as, $\mathrm{m} / \mathrm{z} 61(\mathrm{M}+1)$ is more abundant than $\mathrm{m} / \mathrm{z} 60$ (urea - parent ion). These data point to the presence of a compound which liberates atomic oxygen. Also, the enhancement of $\mathrm{m} / \mathrm{z} 61(\mathrm{M}+1)$ peak relative to $\mathrm{m} / \mathrm{z}$ 60 (M) indicates the presence of hydrogen or proton donor with urea. For the same reason i.e., the presence of hydrogen or proton donor, the intensities of $28,29,30$, and $31 \mathrm{~m} / \mathrm{z}$ increased in ppt-2 spectrum relative to urea spectrum. Moreover, $\mathrm{m} / \mathrm{z} 33$ and $\mathrm{m} / \mathrm{z}$ 34, due to $\mathrm{HO}_{2}{ }^{+}$and $\mathrm{H}_{2} \mathrm{O}_{2}{ }^{+}$were detected, respectively in ppt-2 spectrum, indicating the presence of $\mathrm{H}_{2} \mathrm{O}_{2}$. HNMR spectrum of ppt-2 differ from that of ppt-1 in both signal positions (chemical shift) and the appearance of new signals. This observation can be due to complex formation, such as hydrogen bonding. Moreover, the appearance of two signals at 6.78 and $8.5 \mathrm{ppm}$ in ppt-2 spectrum is related to the formation of a new compound. As a matter of fact, hydrogen peroxide forms adduct with urea via 
hydrogen bonding. Consequently, the signal at $6.78 \mathrm{ppm}$ could be assigned to hydrogen bonded $\mathrm{H}_{2} \mathrm{O}_{2}$ and the downfield signal (8.5ppm) could be assigned to free hydrogen peroxide. This interpretation is based on the disappearance of this signal $(8.5 \mathrm{ppm})$ upon $\mathrm{D}_{2} \mathrm{O}$ shake experiment of ppt2 sample, while the persistence of the upfield signal (6.8ppm). The persistence of $6.8 \mathrm{ppm}$ signal after $\mathrm{D}_{2} \mathrm{O}$ shake experiment could be related to protons engaged in hydrogen bonding, where, complexation, such as, hydrogen bonding hinders H/D exchange. Raman spectra, of irradiated and unirradiated urea samples, differ qualitatively (shift of the characteristic band maxima), as well as, quantitatively (different intensities of the corresponding bands and band shape variation). These differences can be attributed to the engagement of urea in hydrogen bonding with another molecular species, such as hydrogen peroxide. Unfortunately, the band due to O-O stretch (800 1000cm-1) in both ppt-2 and IRS spectra may be masked by $\mathrm{N}-\mathrm{C}$ stretch band (centered at $\approx 1000 \mathrm{~cm}-1$ ). Moreover O-H stretch band of hydrogen peroxide could be masked by group of overlapped bands $>3000 \mathrm{~cm}-1$, in both of ppt-2 and IRS spectra.

Finally, the following facts should be taken in consideration before reporting the conclusion:

1-Urea tends to form adduct with hydrogen peroxide.

2-Ionizing radiation induces formation of hydrogen peroxide in aqueous solution.

3-Urea can enhance the formation of hydrogen peroxide during $\gamma$ - radiolysis of aqueous urea solution.

4- $\gamma$-radiolysis of aqueous urea solution at ambient temperature fulfils the presence of hydrogen peroxide and urea in a circumstance quite similar to that reported for the formation of urea peroxide.

Therefore, it could be concluded that the formation of urea - hydrogen peroxide adduct in gamma irradiated UAS is possible and could not be ruled out.

\section{Acknowledgements}

The author would like to express his highest appreciation for the fruitful discussions of professor A.M. Hassan Rezk and the technical assistance of M. Abdelhameed, and Kh. Hanafy, NCRRT.
References

1-Jacek, Zeglinski;Grzegorz, Piotrowski P.; Ryszard, Pieckos(2006) A study of interaction between hydrogen peroxide and silica gel by FTIR spectroscopy and quantum chemistry, Journal of Molecular Structure,794, 83-91.

2- Taliansky, S.(2005) Urea-Hydrogen Peroxide Complex, Synlett,(12), 1962-1963.

3- Jensen L. , Mortensen P. M., Trane R., Harris P. and Berg R. W. (2009) Reaction Kinetics of Acetone Peroxide Formation and Structure Investigations Using Raman Spectroscopy and X-ray Diffraction, Applied Spectroscopy, 63,(1), 92-97.

4-Ali Reza Pourali, Mersieh Ghanei(2006) Efficient Epoxidation of $\alpha, \beta$-Enones with Polyvinylpyrrolidone Supported Hydrogen Peroxide (PVP-H2O2), Bull. Korean Chem. Soc, 27, (10), 1674-1676.

5-Ripin D.H., Evans D.A.: pKa's of Nitrogen Acids, Chem 206, pKa evans.rc.fas.harvard.edu/pdf/evans_pKa_table. pdf.

6- Ibid, pKa's of pKa's of Inorganic and Oxo-Acids, Chem 206, pKa, evans.rc.fas.harvard.edu/pdf/evans_pKa_table.pdf.

7-Das M., Sen P., Prasad R., Sen P. K.,Geometry Optimization and Second-Order Nonlinear Optical Properties of Urea Hydrogen Peroxide Adduct, Geometry. http://een.iust.ac.ir/profs/Sadr/Papers/nlop4.pdf

8-Henry Papin, Bleaching cottons by aqueous solutions of urea peroxide US $3350161 \mathrm{~A} .(31 / 10 / / 97 \mathrm{~V})$.

9-Chao Shu Yao, John Douglas Waterfield, Ya Shen, Markus Haapasalo and Michael I.MacEntee( 2013) In vitro antibacterial effect of carbamide peroxide on oral biofilm, J Oral Microbiol.5, (10),1-6.

10-Jeffrey, A. Barnes; Thomas, Baum; Li-Min, CHEN; Emanuel, I. Cooper; Lawrence, Dubois; Michael, Korzenski, Removal of metal impurities from silicon surfaces for solar cell and semiconductor applications, Jun Liu, Ben LOCHTENBERG, Laisheng SUN, - WO2012154498 A2. $15 / 11 / 2012$.

11- Narendranath N. V., Thomas K. C. and Ingledew W. M.(2000)Urea Hydrogen Peroxide Reduces the Numbers of Lactobacilli, Nourishes Yeast, and Leaves No Residues in the Ethanol Fermentation,Appl Environ Microbiol.66(10), 4187-4192.

12-Malyaj, Das Prasad R.;Sen,P.(2006) Structural analysis and second-order non-linear optical activity of urea hydrogen peroxide adduct, Indian Journal of Pure and Applied Physics, 44, 554-562.

13-Spinks, J. W. T. and Woods, R. J.(1990) An Introduction to Radiation Chemistry - Third Edition John Wiley \& Sons, Inc, New York, Toronto, pp. 243. 14-Abigail E., Cruz-Hernández, Maria Colin-Garcia, Alejandro Heredia-Barbero, Alicia Negron-Mendoza, Sergio, Ramos-Bernal(2015)Heterogeneous radiolysis 
of urea.Implications in astrobiology and prebiotic chemistry, Open Chem.,13, 172-176.

15-www.h2o2.com, $\mathrm{H} 2 \mathrm{O} 2$ electrical conductivity.

16-Sife-Eldeen, Kh.A.(2008) Performance of Sife Eldeen dosimeter over broad absorbed dose and dose rate ranges of $\gamma-$ radiation and at different temperatures, Iran. J. Radiat. Res.6 (3), 135-140.

17-www.sigmaaldrich.com, Suggestion for cleaning glassware.

18-Jack, DeRuiter (2005) Principles of Drug Action 1, Amides and Related Functional Groups;http://www.auburn.edu/ deruija/pda1_amides. pdf; Spring, 1-16.

19-Frost, Ray L., Kristof, Janos, Kloprogge, J. Theo, Rintoul, Llew J.(2000) Raman spectroscopy of urea and urea-intercalated kaolinites at $77 \mathrm{~K}$, Spectrochimica Acta Part A: Molecular and Biomolecular Spectroscopy, ,56,(9),1681 -1691.

20-George, V. Karas (2005) Trends in Crystal Growth Research, Nova Science Publishers, New York, Chapter: 9, pp.161.

21-National institute of standards and technology (NIST) - $\quad$ Material Measurement Laboratory, webbook.nist.gov.

22-Aina N. Gadanha, Charline R. Rossini, João, P. S. Fernandes and Márcio Ferrarini(2013) Stability of carbamide peroxide in gel formulation as prepared in Brazilian compounding pharmacies. Rev., Bras. Farm., 94 (2),115-119.

23-Fuller,T., Shinohara, K., Ramani, V., Shirvanian, P., Uchida, H., Cleghorn, S., Strasser, P.,Nakagawa,H.,Gasteiger, H.A., Lawy,C.(2008) Proton exchange membrane fuel cells, ; ecstransections, 8,(2), 252-256.

24-Mynard, C. Hamming; Norman, G.Foster(1972) Interpretation of Mass Spectra of Organic Compounds, Academic press, pp 104.

25-Bedjanian,Y., Romanias, M. N., and El Zein, A.(2013) Uptake of HO2 radicals on Arizona Test Dust, Atmos. Chem. Phys.13,6461-6471.

26-Ned, A. Stephenson, Alexis, T. Bell(2005)Anal Bioanal Chem. 2005, 381, 1289-1293.

27-Kazunori Souma, Yasuo Yamamoto, Nobuo Suzuki and Shunichi Fukuzumi(2010) Simultaneous production of $p$ tolualdehyde and hydrogen peroxide in photocatalytic oxygenation of pxylene and reduction of oxygen with 9-mesityl-10-methylacridinium ion derivatives, Chemical Communications,46,(4), 601603.

28-Hori, S., Yamauchi, K., Kuroki, S. and Ando, I.(2002) Proton NMR Chemical Shift Behavior of Hydrogen-Bonded Amide Proton of GlycineContaining Peptides and Polypeptides as Studied by ab initio MO Calculation, Int. J. Mol. Sci.,3, 907-913.

29-Omar B. Ibrahim , Moamen S. Refat, Mahmoud Salman1 , M.M. AL-Majthoub(2012) Chemical Studies on the Uses of Urea Complexes to Synthesize Compounds Having Electrical and Biological
Applications, International Journal of Material Science,2( 3), 67-82.

30-Hydration and Hydrogen Bonds by NMR; COURSE\#1022: Biochemical Applications of NMR Spectroscopy, http://www.bioc.aecom.yu.edu. 2010.

31-Somer, Bekiroglu(2003)Hydroxy Protons in Structural Analysis of Carbohydrates by NMR Spectroscopy and Computational Methods; Doctoral Thesis Swedish University of Agricultural Sciences,Uppsala,pp, 19 .

32-Types of information from NMR spectrum; http://www2.chem.umd.edu/groups/davis/Course/09S C237/090511.pdf.

33-Iwona Ziemecka, Benoît Haut and Benoit Scheid(2015) Hydrogen peroxide concentration by pervaporation of a ternary liquid solution in microfluidics, Electronic Supplementary Material for Lab Chip, 15, 504.

34-Jeffrey,G. A., Saenger, W.( 1994) Hydrogen Bonding in Biological Structures, Study edition, Springer-verlag,pp.127.

35-Raman Spectroscopy, Advanced Physics Laboratory; February 15, 2006.

36- Panarin', E.F., Kalninsh,K.K., Pestov, D.V. (2001)Complexation of hydrogen peroxide with polyvinylpyrrolidone: ab initio calculations. European Polymer Journal, 37, ( 2), 375-379.

37-Wikipedia; https://en.wikipedia.org/wiki/Urea.

38- Ananthakrishnan, R.(1937) Raman spectra of crystal powders. IV. Organic and inorganic compounds.Proc.Indian Acad.Science,5, 200-221.

39-Krishnamurti, P.(1931) Raman spectra of some organic crystals and solutions, Indian J. Physics,6,309-317.

40- Malyaj Das, Prasad R. and Sen P.(2006) Structural analysis and second-order non-linear optical activity of urea hydrogen peroxide adduct. Indian Journal of Pure and Applied physics,44, 554 -558.

41- Otto, C., De Mul F. F. M. and Greve, J.(1987) A Raman spectroscopic study of the interaction between nucleotides and the DNA binding protein gp32 of bacteriophage T4,Biopolymers, 26 (10), 1667-1689.

42-Eudes, E. Fileti, Marcos, A. Castro, Sylvio Canuto(2008)Calculations of vibrational frequencies, Raman activities and degrees of depolarization for complexes involving water, methanol and ethanol, Chemical Physics Letters, 452, 54-58.

43-Nick Nagels, Dieter Hauchecorne and Wouter A. Herrebout(2013)Article Exploring the C-X... Halogen Bonding Motif: An Infrared and Raman Study of the Complexes of CF3X (X $=\mathrm{Cl}, \mathrm{Br}$ and I) with the Aromatic Model Compounds Benzene and Toluene, Molecules 18, 6829-6851.

44-Raman Data and Analysis - Raman Bands http://www.horiba. com.

45-Quantitative \& Qualitative HPLC; http://www.chromacademy.com. 
46-Durickovic I, Thiébaud L, Bourson P, Kauffmann T, Marchetti M.(2013) Spectroscopic characterization of urea aqueous solutions: experimental phase diagram of the urea-water binary system. Applied Spectroscopy, 67 (10),1205-1209.

47-Puviarsan, N., Arjunan, V. and Mohan, S.(2002) FTIR and FT-Raman Studies on 3Aminophthalhydrazide and N-Aminophthalimide. Turk J Chem. 26, 323- 333.

48-Manuel F. Ruiz-Lopez,Francisco J. Olivares(2014)9th Congress on Electronic Structure: Principles and Applications, Springer, ESPA p.119.

49-Martin, Chaplin, Water Structure and Science, http://www1.1sbu.ac.uk.

50-Aldo, Domenicano;Istvan, Hargittai Strength from Weakness: Structural Consequences of Weak Interactions in Molecules, Supermolecules, and Crystals(2001)Springer,pp283.

51- Frost, Ray L., Matt L. Weier, Theo Kloprogge, J.(2003)Raman spectroscopy of some natural hydrotalcites with sulphate and carbonate in the interlayer,Journal of Raman Spectroscopy, 34(10) 760-768.

52-Spinks, J. W. T.; Woods, R. J.(1990) An Introduction to Radiation Chemistry 3rd Edition JohnWiley and Sons, Inc., New York, Toronto,pp 255.
53-Navarro-Gonzalez, R., Negron- Mendoz, A., and Chaconr, E.(1989) The $\gamma$-irradiation of aqueous solutions of urea. Implications for chemical evolution. Origins of life and evolution of the biosphere, 19(2),109-118.

54-Erzsébet Illés, Anna Tegze, Krisztina Kovács, Gyuri Sági, Zoltán Papp, Erzsébet TakácsL ászló Wojnárovits (2017) Hydrogen peroxide formation during radiolysis of aerated aqueous solutions of organic molecules, Radiation Physics and Chemistry, 134, 8-13.

55-Practical Group Theory and Raman Spectroscopy, Part II: Application of Polarization, (2014) www.spectroscopyonline.com.

56- Ray L. Frost, Janos Kristof (1997) Intercalation of Halloysite: A Raman Spectroscopic Study, Clays and Clay Minerals,45(4)551-563.

57-Jehlička,J., Edwards, H. G. M., Culka, A.(2010) Using portable Raman spectrometers for the identification of organic compounds at low temperatures and high altitudes: exobiological applications, Philos Trans A Math Phys Eng Sci., 13;368(1922)3109-3125. 